CHARLES RIDDLE teaches journalism at the Waikato Institute of Technology and is president of the Journalism Education Association of New Zealand (JEANZ).

\section{Optimistic view of the Pacific's}

\section{Fourth Estate and education}

Mekim Nius: South Pacific media, politics and education, by David Robie. Suva: University of the South Pacific Book Centre; Auckland: Auckland University of Technology/South Pacific Books, 2004. 306 pp. ISBN 98201 0584 6/1 877314307.

OOME years ago while lecturing

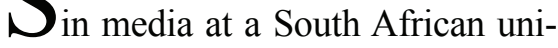
versity I developed a bit of a sideline as a peripatetic journalism teacher, peddling my wares around Southern Africa to church groups, the United Nations and nongovernmental organisations. It was wellpaid work on the whole, especially the UNESCO contracts. It was also relatively easy. There was a defined short term commitment to the students, an expectation that one could teach only 'so much' in the limited time available,

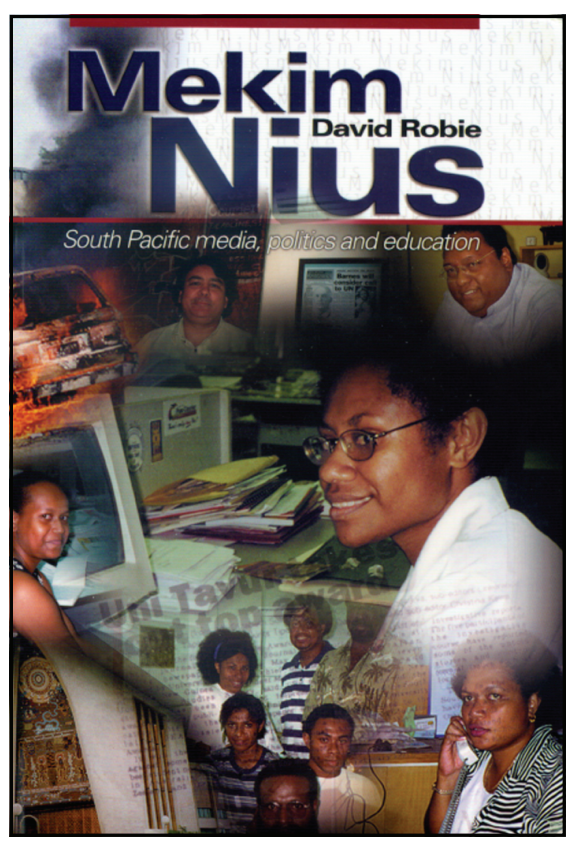

and that there would be little assessment of learning. It was, of course, very different from university.

On one such deal I spent a week in the tiny, impoverished and landlocked nation of Lesotho teaching the finer points of news writing to a mixed bag of eager radio, print and freelance journalists. All of them were poor by Western standards and most could recount tales of threats from tribal authorities and politicians. The week went as well as these things do, the students polite, their teacher earnest but out of touch with local issues. I was the stereotypical parachute expert with a kitbag of skills. We all worked hard but I'm not sure 
they learned much. Such courses are probably at their most effective as expensive networking opportunities. Some time later Lesotho was caught up in a coup. The media did not fare well in their reporting.

And so it was that I found myself in a state of comfortable déja vu as I read Dr David Robie's latest book. Mekim Nius: South Pacific media, politics and education is a comprehensively researched study of the state of journalism and journalists in Papua New Guinea and Fiji. Robie, who beside his long Pacific teaching experience has worked in Southern Africa and Kenya, would have been aware of the African parallels while researching his book.

Beyond the fine detail (and there is plenty of this in Mekim Nius) many fledgling states worldwide are under threat from globalisation, ethnic violence, and a tempting availability of guns. Ensuring their progression to mature democracies is partly the responsibility of their local cadres of low status, poorly paid journalists who, Robie reminds us, are increasingly subject to the temptations of freebies, junkets and 'envelope journalism'. These are familiar themes to those who have spent time in developing nations.

At its core, Mekim Nius argues a clear position university level edu- cation is central to the health of South Pacific journalism and its democracies. To do this Robie is ambitious with the book's scope, declaring three broad aims: a study of the critical influence of tertiary education on $\mathrm{Pa}$ cific journalists and their profession; an analysis of the political, economic and legal frameworks in which Fijian and PNG journalists have operated since independence; and an outline of the development of journalism education in the South Pacific.

Any one of these could form the basis of a separate tome but, for good measure, Robie also discusses the influence of development journalism on a Pacific style of journalism.

This book's strength lies in the triangulation research method: newsroom staff surveys, interviews, and library and archive ferreting. Add to this Robie's nine years in Fiji and PNG as head of two of the university-based journalism schools and the overall result is impressive. Mekim Nius now is clearly the standard text for any discussion of the Fiji and PNG news industries.

But, as with all heavily empirical studies, it will date (the latest survey quoted was completed in 2001 for instance) and one already feels the need to call for a second edition. That aside, the wealth of data provided is so good as to be overwhelming and, 
at times, the reader may find themselves unable to see the wood for the trees. This is perhaps a consequence of trying to achieve so much and his index inevitably struggles. (For example, Robie tells us the first newspaper website in the South Pacific was established in 1995, but you'll search hard to find any reference to this in the index.) However, there are excellent roadmap summaries at the end of each of his eight chapters for those readers who may find themselves losing sight of the argument amid the sea of tables, facts and anecdotes.

Woven throughout the book is a discussion about the shape journalism education in the South Pacific should assume. One thread is a trip through the many longterm expat educators who spent time at the various universities: New Zealanders Michael King, Murray Masterton and Ross Stevens, Norwegian Trine Östlyngen, Father Trevor Cullen (ex $\mathrm{BBC}$, Vatican Radio and the Malawi Broadcasting Corporation), and an American of Croatian descent, $\mathrm{Fa}$ ther Frank Mihalic, to mention a few. It was Mihalic, aware of the need to get local people trained as trainers, who was fond of noting that a missionary was only successful when he put himself out of a job. Another thread follows a discussion of the relative efficacy of short donorfunded courses. Robie worries training has become a captive of donor agencies in which the training is often tailored to the donor's needs rather than those of the journalists.

The most beneficial outcome, he argues, would be aid that supports capacity building for the homegrown (read university-based) journalism schools. His belief in the three South Pacific universities (UPNG, USP and the Divine Word University) in journalism training is clearly put in his conclusion (p. 248):

News managements, particularly in Fiji where they could emulate Papua New Guinea, need to shed their haphazard attitude and adopt real commitment to professional journalism education provided by the Pacific universities ... Journalists with a quality allround tertiary education with strong exposure to disciplines such as business, economics, geography, government, history/politics, human rights, language (English for mainstream media) and literature, and sociology would be a sound investment. Too many newsrooms have general reporters without the skills to do specialised coverage. A problem solving ability along with critical and analytical skills, strong characteristics of the university journalism courses, is also important. 
This is essentially an optimistic book by an author who believes tertiary education will produce a better Fourth Estate. Robie notes New Zealand once led the way in journalism training in the Pacific, a position it has lost to Australia's Ausaid. He reminds readers it was New Zealand that established the South Pacific's first journalism school at UPNG in 1975. He is clear that journalism now is in a better state than before, especially in PNG where a remarkably high percentage of journalists (81 per cent) now have a diploma or degree behind them.

It is a moot point whether those who determine education funding will be swayed by his arguments that universities best provide such education or whether, indeed, the funding debate is worth the candle.

At the risk of overplaying the African parallel, Zimbabwe has recently demonstrated that educated newsrooms cannot necessarily defend democracy. There are few guarantees that can be proffered to funders, but Robie's book is a compelling argument for continuing to try to bolster the Fourth Estate for what lies ahead.
DR DAN BEDGGOOD is a lecturer and researcher at the University of Canterbury. He has published on Pacific cultural encounters and representation.

\section{Hounding the 'great voyager'}

The Trial of the Cannibal Dog: Captain Cook in the South Seas, by Anne Salmond. Auckland: Penguin, 2004, 506 pp. ISBN 0141021330.

To tatou tipuna, ko Kapene Kuki [Our ancestor, Captain Cook] (Te Rangihiroa, cited in Salmond, 2004, p. 425).

COOK is a figure who looms large in the cultural history of the $\mathrm{Pa}$ cific, sailing through the region over the best part of a decade in the late eighteenth century, but leaving a wake ever-expanding to the present. Part of this 'wake' is evident in the considerable space occupied in our literary imagination; yet the chosen pose for this cultural 'ancestor' is variously contended depending on the imaginer's own reflection on history. Cook has had a long reputation as an idealised 'great voyager' and Enlightenment figure, meticulous and rea- 